\title{
Socio - Economic Consequences of Unemployment in Kosovo 2008-2012
}

\author{
Lirim Lani \\ European College Dukagjini/ Economic Faculty, Pejë, Kosovë \\ lirimlani_1994@hotmail.com
}

Kastriot Gjocaj

European College Dukagjini, Pejë, Kosovë

\section{Doi:10.5901/ajis.2014.v3n2p223}

\section{Abstract}

Unemployment in Kosovo brought a lot of consequences; however the main consequences are emphasized in socio economic ground. We will elaborate the economic and social consequences in this work. The greatest consequences that unemployment brought in social aspect during the period 2008-2012 are mainly emphasized on the increase of criminality on the young population, significant migration which is being seen as the only and inevitable opportunity to a good economic solution. The greatest consequences of unemployment from the economic ground are emphasized on direct investments of Kosovo Government, increase of the expenses for social cases, decrease of investments on education and agriculture, decrease of GDP per capita, increase of budgetary deficit and trade deficit also it has influence on the decrease of economic investments from remittances.

Keywords: Criminal potential, Migration, Education, Agriculture, Remittances, GDP.

\section{Introduction}

Unemployment in Kosovo not just during this period, but also from after the war is challenged with a high rate of unemployment norm, which is bringing a high and notwithstanding cost with its real economic development

The greatest consequences which the unemployment is bringing, like the greatest macroeconomic problem of Kosovo, are mainly in the social field and in the economic field. The intertwining of many factors that have caused this quite high degree of unemployment concluded to a degree that the consequences are emerging gradually and these consequences have a quite negative effect on social and economic development of Kosovo.

Migration is the biggest consequence in social area, caused by unemployment, wherefrom today Kosovo is losing its pearl and the only hope for economic development, which is youth. Gradually, this phenomenon is becoming the only way of salvation from poverty in Kosovo, whereas the consequences of the bitter migration after some years shall be very painful, not just for Kosovo, but also for Albanian people itself.

The decrease of expenses in education and agriculture sector are some of the many consequences, which unemployment brought in Kosovo. Kosovo shares a very small percentage in the two abovementioned branches, whilst the need and demand for these two branches requires a greater attention knowing the fact that the pillars of economic development are based on these two sectors.

\section{Social Consequences of Unemployment in Kosovo}

Unemployment as the greatest macroeconomic problemalso has its influence in social branch, by affecting in the direct and indirect aspect. Kosovo as a country in transition has the youngest population in Europe, however this part of society is the most attacked from unemployment and that the lack of jobs influences negatively in the psychology of a person, by making it a real potential to commit crimes, since according to NAN a person that doesn't have a safe in future, he is ready to commit different crimes to survive. 


\subsection{Criminal potential}

The increase of the number of unemployed people in Kosovo can influence negatively in commission of different crimes, because according to KP, many of the criminals are unemployed persons, and they do the crime to survive. According to ASK in the extreme poverty a person lives with 1,02€ per day. According to KP the number of arrested people for commission of different crimes is increasing every year, by making Kosovo that in 1000 inhabitants have 13 arrested persons, which makes Kosovo the country with the highest criminal rate, since one of the indirect factors which is unemployment effects on commission of the crimes.

Table 1. The number of arrested persons 2010-2012 according to KP

\begin{tabular}{|c|c|}
\hline Year & Number of arrested people \\
\hline 2010 & 21,118 \\
2011 & 22,630 \\
2012 & 23,116 \\
\hline
\end{tabular}

Source: MIA, Annual report $(2010,2011,2012)$

From table 1 we see an increase of the number of the arrested persons, where from 2010 to 2011 the number of arrested persons increased for $7.16 \%$, whereas from 2010 to 2012 it increased for $9.46 \%$.

According to GJSK in 2012, 2292 criminal cases were dealt with, which had the target the private property and its types (GJSK, Work Report 2012).

Diagram 1. The number of minors sentenced by Kosovo Courts

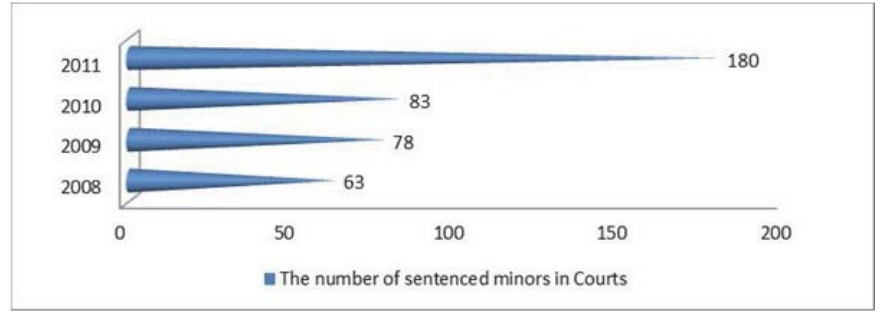

Source: SAK, Statistics of Jurisprudence for Minor persons (2011)

This diagram shows the number of minors sentenced is just increasing; one of the causes is the high number of young population without a job. From 2008 to 2011 the number of sentenced minors increased for $185.71 \%$.

\subsection{Migration}

The migration problem within Albanian started some time ago, for many reason, the migration reasons before 1999 were for political reasons and exclusion from Serbian forces, whereas after 1999 the migration happens mainly for economic reasons.

According to the unofficial data in Kosovo, every year around 30,000 thousand people migrate to Europe and other continents, which is a colossal loss for Kosovo, because every year a small town is moving away from the country.

Although Kosovo used to be a source of migrating workers from the beginning of the twentieth century, their exact number is still unknown; therefore it is reported as an approximate number. The number of Kosovo migrants that live abroad is estimated to be between 220,000 and 500,000(UNDP, Study on remittances in Kosovo 2012). 
Table 2. The dissipation of Migrants through the migration waves of UNDP

\begin{tabular}{|l|c|}
\hline Migration wave & Percentage of Migrants \\
\hline I. Before 1989 & $8.8 \%$ \\
\hline Il.1989-1997 & $25 \%$ \\
\hline III.1998-1999 & $12.6 \%$ \\
\hline IV. After 1999 & $53.6 \%$ \\
\hline Total & $100 \%$ \\
\hline
\end{tabular}

Source: UNDP, Study on remittances in Kosovo(2012)

Table2 shows that the biggest wave of migration occurred after 1999(53.6\%), since Kosovo became free from a 100 year under rule and the economic situation after the war turned that a vast majority of population leave Kosovo.

According to UNDP, the vast majority (70\%) declare that the economic situation are the main intention of migration, $10 \%$ plan to migrate to get married or for family union, whereas less than $2 \%$ plan to continue education (UNDP, Study on remittances in Kosovo 2012).

However, this migration every year and more is becoming an intention for $95 \%$ of the youth in Kosovo; this is a very concerning issue, because we are losing a lot from this, especially the economy of Kosovo, poor in anyway. This is happening because youngsters are finishing the university degree education and remaining without a job. This makes migration as their only solution.

\section{Economic consequences of the unemployment in Kosovo}

The current economy of Kosovo is having decreasing trend because of the many factors that we mentioned in this work; however the biggest punishment is being caused by the unemployment, especially the long term unemployment.The unemployment as a macroeconomic problem is bringing huge obstacles to the economy in developing of meaningfulpolitics of the economy.

The consequences from the unemployment have a huge cost to our economy, since it brings in every different barrier in every economic sphere; therefore concentration in economic consequences of the unemployment is crucial for removing the obstacles that arise on the way of economic development.

Today when we talk about unemployment, we should know that its degree is high and that the solutions for it are missing a lot, however the more concerning issue is the fact that there is a missing statistics about the unemployment norm in Kosovo, where there is discrepancy of data of many local institutions and international institutions that give different figures in this field.

\subsection{Unemployment rate in Kosovo}

The current norm of unemployment is extremely high for the current economic circumstances; however it is the highest in Europe $^{1}$. The problem of this field in continuing to increase in negative trends, especially on the young population, where the unemployment norm is extremely high. Gradually Kosovo is tightening the labor market.

Diagram 2. The number of unemployed people and free vacancies according to MLSW

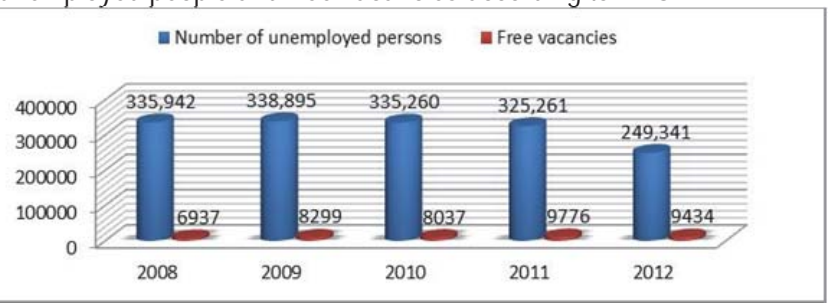

Source: MLSW, Labor and Employment(2008, 2009, 2010, 2011, 2012)

\footnotetext{
${ }^{1}$ According to the late data of WB, Kosovo in $10^{\text {th }}$ place in the world for the unemployment rate from 198 countries of the world.
} 
The diagram shows a huge disequilibrium of the number of unemployed persons and the free work places, where for 1 workplace the 40 unemployed persons apply, which means that in order to get a job the chances are 1:40. The number of active population for labor is somewhere around 1,000,000 persons from 15 - 64 years old (Riinvest, 2003), however when we add the fact that the unemployment degree with the demand for work are far away from each other, the chance to get this number of people employed with the current economic increase, it turns that around $20-25$ years should pass and then the labor market will be in equilibrium. In 2012 we see a decreased number of unemployed people; however this is not because of their employment, but for the two main reasons, the first one they do not register at the employment centers, since they lost the trust that they will get a job and the second is that they have migrated out of the country.

Diagram 3. The unemployment norm for female gender and male gender according to MLSW

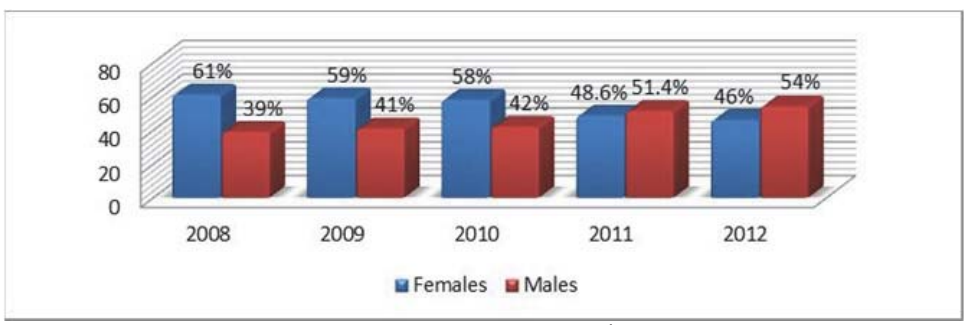

Source: MLSW, Work and Employment (2008, 2009, 2010, 2011, 2012)

The gender that is attacked the most with unemployment is the female gender with an average of above $60 \%$ of the general number of unemployed persons, whereas the masculine gender is less attacked with this problem.

Table 3. The unemployment norm in young population according to MLSW

\begin{tabular}{|c|c|}
\hline Years & Unemployment degree in young population \\
\hline 2008 & $74.31 \%$ \\
\hline 2009 & $74.73 \%$ \\
\hline 2010 & $75.88 \%$ \\
\hline 2011 & $76.67 \%$ \\
\hline 2012 & $86.43 \%$ \\
\hline
\end{tabular}

Source: MLSW, Work and Employment (2008, 2009, 2010, 2011, 2012)

The young population in Kosovo is the black spot of the unemployment, when it is known that the young population in Kosovo consists of $63 \%$ of the active population for labor (Riinvest, 2011), however this fact is an additional evidence that the degree of $86 \%$ of unemployed persons shows that institutions do not stimulate this sector at all for the economy of Kosovo and then that is bringing evident consequences in practice, where the only pillar for economic growth is vanishing abroad or it is wandering around and because of that fact the unemployment is destroying the heart of the economy of Kosovo.

Diagram 4. Employment norm in Kosovo according to MLSW

Employment Degree

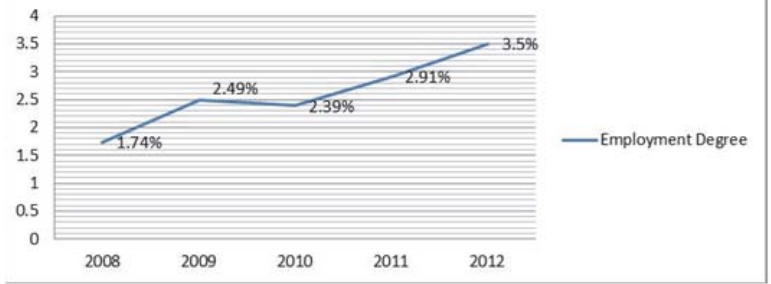

Source: MLSW, Work and Employment (2008, 2009, 2010, 2011, 2012) 
The employment in Kosovo is so small that the growth rhythm is somewhere $0.44 \%$ annually, where the need for employment is urgent, whereas the data show that the employment growth rhythm is very small, in order to recover Kosovo needs to have employment growth of about $9 \%$ in the next 3-5 years.

\subsection{Influence in Development Politics of GK²}

The fact that the conditions and the economic situation are extremely bad, it is an indicator that the development politics of GK focus only in some sectors, where the most important is the focus in development of road infrastructure, Kosovo Government shared 20.5\% in 2012 (MF, Budget 2012) of the budget of the Republic of Kosovo, whereas for 2011 shared $24.01 \%$ (MF, Budget 2011) of the general budget.

The high unemployment degree is a key factor that development politics shall focus on those fields, where the physical needs for the economy are essential, whereas the entire focus in $1 / 4$ of the budget for road infrastructure is somehow high, when the needs of the population of Kosovo are known, however the budgetary allocation is extremely not proportional with the demands, because the sectors of direct development of economy like agriculture and education have an unfair partition, thereby the economy of the country is suffering the most. The only means to reduce the unemployment from GK is through expenditures in infrastructure, but this is a temporary mean, since the employment in this field is short term.

\subsubsection{Increases the expenses for social assistance and other categories}

The high unemployment makes the country focus a part of the budget in social assistance, and they influence directly in decrease of subsidies and investment of GK in crucial sectors of economic development.

Table 4. Expenditures of social assistance for poor families in Kosovo according to MF

\begin{tabular}{|c|c|}
\hline Year & Expenditures of Social Assistance \\
\hline 2008 & $26,118,831.00 €$ \\
\hline 2009 & $30,412,081.00 €$ \\
\hline 2010 & $28,577,179.00 €$ \\
\hline 2011 & $28,257,596.00 €$ \\
\hline 2012 & $28,664,339.00 €$ \\
\hline
\end{tabular}

Source: MF, Budget (2008, 2009, 2010, 2011, 2012)

These expenses are for 34,867 families that receive social assistance; this budget is the same with the one of the ministry of agriculture. The cost of social assistance is huge, since together with the investments in infrastructure make $3 / 5$ of the Kosovo budget. The cost from 2008-2012is 142,030,026 € or 2.33\% annual GDP of Kosovo.

\subsubsection{Decreases investment in Education and Agriculture}

The huge concentration in investments in infrastructure and the expenditures of social assistance make that the main departments of economic development like education and agriculture be left aside, because the development politics concentrate in other fields. The agricultural potential to employ and produce is extraordinarily great that if that part of infrastructure and social assistance would be invested, there would be over $10 \%$ of economic growth.

The education as a field where the work cadre is educated for market is losing its primary function, by converting into a producer if the cadres that have their only destination European and American market.

GK in 2011 for the development of the agricultural sector has shared $1.06 \%$ (MF, Budget 2011) of its general budget, whereas for education shared $\mathbf{2 . 8 2} \%$ (MF, Budget 2011), which is an extremely low percentage for these pillars of the Economy of Kosovo, whereas for 2012 for agriculture has shared 1.57\%(MF, Budget 2012)and for education $3.01 \%(M F$, Budget 2012). With these partitions the economic future is pale and the educated cadre is gradually leaving

\footnotetext{
2 Government of Kosovo
} 
Kosovo, because Kosovar market cannot accept them, in lack of state support.

Aside from losing a lot in decrease of investments in education and agriculture caused directly from huge unemployment, we are losing the only economic hope which is the "gateway of the brain"3from Kosovo, every day educated people is flooding in European markets, in state of contributing to the economic development.

If in the next years there will be no work on improving the conditions to employ employment youngsters that are educated in the country and abroad, then they will be taken by the European market, because till 2020 Europe will need 20,000,000 workers and other specialized professionals in differed grounds (Kajtazi, 2012).

\subsection{Increase the budgetary deficit}

When unemployment is over $40 \%$, the government as main tool has the increase of governmental expenses and the decrease of taxes (Shala, 2012), however this doesn't cause high budgetary deficit. Today we are sinking with a huge budgetary deficit, because the chances to meet these obligations are very small and that GK in the next years may create a dependency from the loans of local banks and of other countries.

Diagram 5. Budgetary deficit according to MF

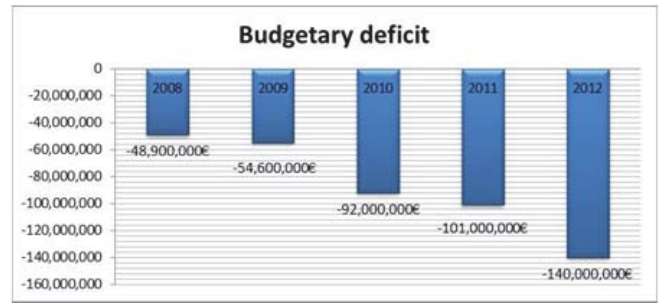

Source: MF \& MEF,Budget (2008, 2009, 2010, 2011, 2012)

The accumulated debt in years in Kosovo is as a consequence of huge expenditures in order to decrease the unemployment norm, however this budgetary norm made that in future decrease governmental expenses, since a part of them shall go to cover the current debt. This problem brings other budgetary implications by cutting the expenses in several sectors of different fields that take part in Kosovo budget.

\subsection{Increases the trade deficit}

The lack of meaningful privatization and the high unemployment rate brought h economy of Kosovo to a condition that in state of fulfilling its production needs it imports foreign productsthat can easily be produced in Kosovo. Furthermore, a lack of a trade politics makes the producers become unstable in production. Trade deficit is causing enormous consequences, because many businesses are closing their activity because of the uncontrolled and non-quality import.

Diagram 6. Trade deficit according WB

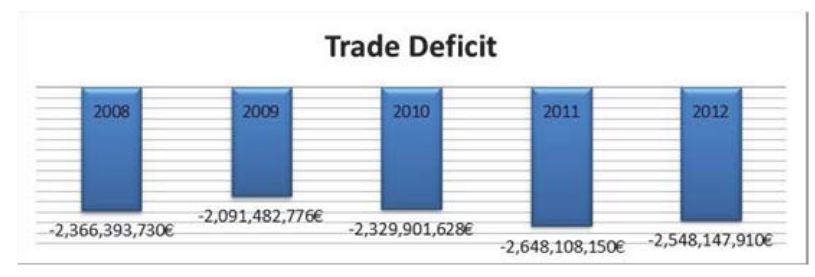

Source: World Bank (2013)

\footnotetext{
${ }^{3}$ Term that is used for the persons that want to study out of their country, due to study causes they stay further in those countries.
} 
Kosovo has the climate and a very fertile land, but in trade that is the opposite,because from 2008-2011 Kosovo imported $1,428,115 €($ ASK, 2011)food products, whereas exported only $65,496 €$ (ASK, 2011)food products, it means $954.11 \%$ imports are higher than exports for food products,therefore the high deficit is becoming a cureless "cancer" for Kosovo.

\subsection{The influence in GDP per capita /annual}

After the war Kosovo was in a chaotic situation, in the aspect of the economy and other fields, where hundreds of enterprises were destroyed, however this is not a reason that today 14 years and the economic situation should not change; because the countries of the region that came out of the same war today they have more developed economies.

The lower level of production determines the decrease of GDP, since a high trade deficit is a barometer that the unemployment is the factor that decreases the production, and by reducing production the GDP goes down.

Diagram 7. GDP per capita according to WB

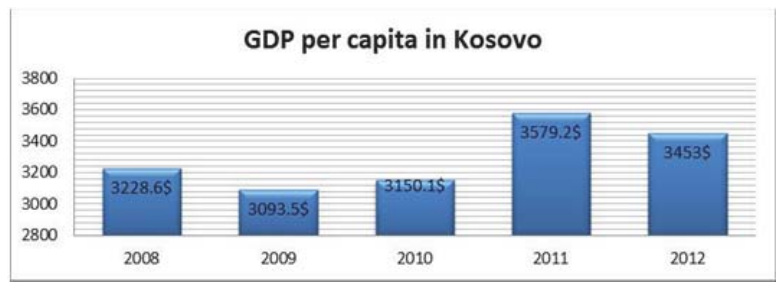

Source: World Bank (2013)

Such low scale of incomes of GDP per capita is the lowest in the region, where Kosovo is the country with the lowest incomes in Europe, not just in the region; the diagram shows a true picture that GDP per capita is decreasing even more.

Such low scale of GDP per capita derives from a lower annual GDP degree, where Kosovo in the range of the countries of the region has the half of GDP of what the countries of the region have.

Diagram 8. Annual GDP of Kosovo, Albania, Serbia, and Macedonia according to WB

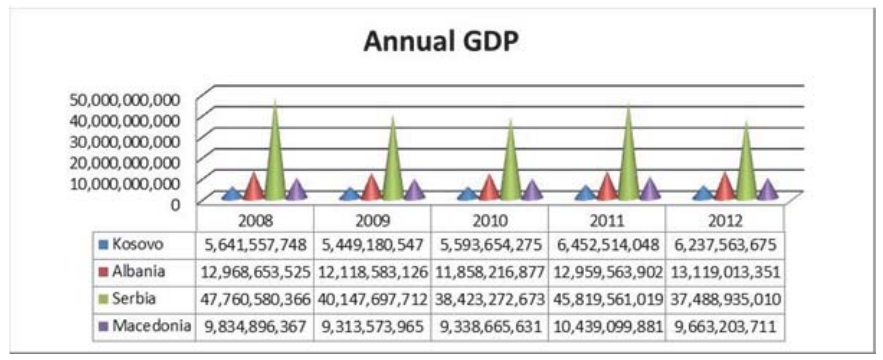

Source: World Bank (2013)

\subsection{Affects the decrease of economic investments from remittances}

The only hope of survival of Kosovo population after the war was the remittances from migrants. They make $1 / 3^{4}$ of Kosovo population. However, the remittances should also be having another dimension of investments in businesses, because what really makes Kosovo different is that the most of the remittances are used for consumption, whereas other 
countries use remittances for investments in economy. Remittances make $9.54 \%$ (CBK, Monthly Statistical Bulletin

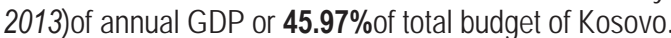

The high unemployment made that our diaspora concentrate more in their remittances for consumption, since families survive with these remittances. Nearly half of remittances in cash are used for consumption, nearly $18 \%$ are used for construction of houses and reconstructions, $17 \%$ for health issues, $15 \%$ for education and just a modest part of $3 \%$ are used for business investment (Riinvest\& Ministry of Diaspora, 2011).

Diagram 9. Remittances in Kosovo 2008-2012 according to CBK

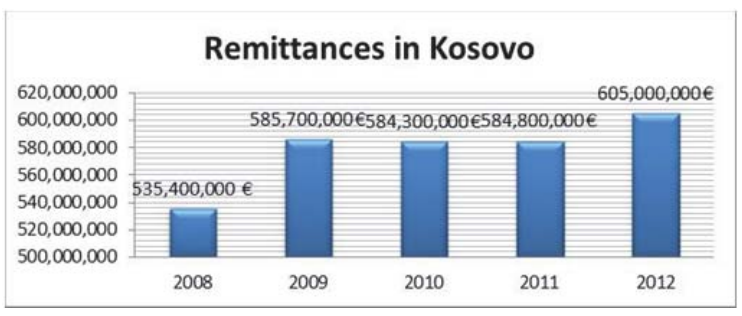

Source: CBK, Monthly Bulletin (2013)

\section{Conclusions and Recommendations}

The unemployment is gradually bringing an unaffordable degree of its consequences. Kosovo every day is confronting economic crises which are brought by extremely high unemployment rate.

The biggest consequences of the unemployment in Kosovo from 2008 - 2012 are: criminality, migration, increase of the governmental expenses in physical aspects of economy, reduction of investments in education and farmers, increase of trade deficit, increase of budgetary deficit, decrease of annual GDP and the decrease of economic investments from remittances.

The recommendations for solution of these economic problems would be treated in general manner by:

1. Creation of a fund for employing youngsters, where every citizen and economical business would contribute in different ways for the employment of youngsters;

2. Stimulation on creating banks with agriculture character, where they would be giving loans only for the development of agriculture;

3. Increase of expenses in agricultural sectors and education by the Government of Kosovo;

4. Stimulation of local producers by decreasing the taxes;

5. Increase of customs taxes for import, because it would directly affect in total incomes of Kosovo and would reduce imports;

6. Stimulation to channel the remittances in economic investments, by creating administrative and fiscal facilities;

\section{References}

The Government of the Republic of Kosovo. Work and Employment (2008) Prishtina: Ministry of Labor and Social Welfare. The Government of the Republic of Kosovo. Work and Employment(2009) Prishtina: Ministry of Labor and Social Welfare The Government of the Republic of Kosovo. Work and Employment (2010) Prishtina: Ministry of Labor and Social Welfare. The Government of the Republic of Kosovo. Work and Employment (2011) Prishtina: Ministry of Labor and Social Welfare. The Government of the Republic of Kosovo. Work and Employment (2012) Prishtina: Ministry of Labor and Social Welfare. Riinvest (2003) Labor market and unemployment in Kosovo. Prishtina Kosovo Judicial Council. Work Report for (2012) Prishtina: Supreme Court of Kosovo. Ministry of Internal Affairs. Annual Report (2010) Prishtina: General Police Directory. Ministry of Internal Affairs. Annual report (2011) Prishtina: General Police Directory. Ministry of Internal Affairs. Annual report (2012) Prishtina: General Police Directory. World Bank (2011) Migration and economic development in Kosovo. Prishtina The Government of the Republic of Kosovo. Work activity (2012) Prishtina: Ministry of Labor and Social Welfare. The Government of the Republic of Kosovo. Monthly Statistical Bulletin (2013) Prishtina: Central Bank of Kosovo. Friedrich EbertStiftung\&Riinvest(2011) Development of the private Sector. Prishtina 
The Government of the Republic of Kosovo. JudicialStatistics for Minor Persons (2011) Prishtina: Statistics Agency of Kosovo. UNDP (2013) Study on remittances in Kosovo 2012. Prishtina

The Government of the Republic of Kosovo. Law on budget of the Republic of Kosovo (2012) Prishtina: Ministry of Finance.

The Government of the Republic of Kosovo. Law on budget of the Republic of Kosovo (2011) Prishtina: Ministry of Finance.

The Government of the Republic of Kosovo. Law on budget of the Republic of Kosovo (2010)Prishtina: Ministry of Finance.

The Government of the Republic of Kosovo. Law on budget of the Republic of Kosovo (2009)Prishtina: Ministry of Economy and Finance.

The Government of the Republic of Kosovo. Law on budget of the Republic of Kosovo (2008)Prishtina: Ministry of Economy and Finance.

Shala, A. (2012) The Transformation of the Economic growth in development. Prishtina.

Kajtazi, F. (2012) Dimensions of the unemployment phenomenon in Kosovo. Prishtina.

Riinvest\&Ministry of Diaspora (2011)Economic Influence of diaspora. Prishtina.

World Bank (2013). "GDP per capita",The World Bank. Can be found athttp://data.worldbank.org/indicator/NY.GDP.PCAP.CD(08 July 2013)

World Bank (2013). "Annual GDP",The World Bank. Can be found at http://data.worldbank.org/indicator/NY.GDP.MKTP.CD(08 July 2013)

The Government of the Republic of Kosovo. Exports and Imports (2011) Prishtina: Statistics Agency of Kosovo. 
